\title{
An Interview with Landon Pearson: On the Role of a Commissioner for Canada's Children
}

\author{
Daniella Bendo \\ Doctoral candidate, Law and Legal Studies \\ Carleton UniversityOttawa,Ontario,daniellabendo@cmail.carleton.ca
}

\section{Introduction}

The gradual implementation of the United Nations Convention on the Rights of the Child (UNCRC, 1989) over the past 25 years in the 196 countries that have now ratified it, has led to an increased understanding of children as citizens with fundamental rights (Mitchell, 2015; Mitchell \& Moore, 2012; Senate of Canada, 2007). Canada ratified the UNCRC in 1991 and made its own commitment to respect, promote and protect these rights. As an internationally engaged and widely respected country, Canada played a significant role during the 10 years it took to draft the UNCRC (from 1979 to 1989) by facilitating communication amongst over 40 countries in the UN working group; these countries reflect diverse religious, ideological, cultural and political values. Canada also actively encouraged the signing and ratification of the Convention. However, when Canada celebrated the $25^{\text {th }}$ anniversary of its own ratification of the UNCRC in 2016, some lamented the continuing lack of awareness and knowledge of the Convention amongst Canadian young people (Senate of Canada, 2007).

As Canada celebrates its $150^{\text {th }}$ year, the $35^{\text {th }}$ anniversary of the Canadian Charter of Rights and Freedoms, and the $40^{\text {th }}$ anniversary of the ratification of the Canadian Human Rights Act, Canada has yet to establish a statutory national human rights institution or federal Commissioner for children. In August 2015, during an election announcement in Montréal, Federal Liberal Party Candidate Marc Garneau promised that his party would appoint a Children's Commissioner if given the mandate to form government. With the current change in 
government, Justin Trudeau's Liberal Party of Canada has recently faced calls to follow through with the election campaign promise to create a children's Commissioner to ensure government policies benefit young people (The Canadian Press, 2017). Although ample research in Canada exists on the rights of children and youth (Bendo, 2015; Howe and Covell, 2005; Mitchell, 2015; Senate of Canada, 2007), little attention has been paid to the growing role and responsibilities of domestic Child and Youth Advocates (United Nations Committee on the Rights of the Child, 2003, 2012). International perspectives on this issue reveal a similar knowledge gap (see Payne, 2002; Thomas, et al., 2010 for UK exceptions).

Over 60 countries have appointed a Commissioner or an Ombudsman for children and youth at the national level to promote and protect children's rights; Canada is not among them. This is partly due to Canada's federal structure and split jurisdiction with respect to children's issues. At almost every provincial and territorial level of government, child and youth advocates serve as independent officers of their respective legislatures. Together they comprise the Canadian Council of Child and Youth Advocates who work on behalf of vulnerable children and youth to the best of their ability even though they do not have legal jurisdiction neither individually nor collectively. However, their mandates do focus on the protection and promotion of the rights of children under the care of their provincial or territorial governments. This means that across the country, education is completely excluded from the Advocate Offices' mandates (Bendo, 2015; 2016). Furthermore, they are not mandated to intervene on issues that fall under federal jurisdiction. As a result, the advocates are not able to assist certain groups of young people including Indigenous youth, immigrant and refugee children and other at-risk youth when they are caught by these jurisdictional divides.

Proponents who wish to see the establishment of an Office of the Federal Commissioner for Canada's children and youth argue that such a Commissioner would have the power to monitor, assess and report on services provided to children under federal jurisdiction, advocate for the rights of children and young people throughout Canada and raise awareness of the UNCRC (Senate of Canada, 2007). While the role of a Commissioner for Canada's children has the potential to improve child-service delivery, implementation of the UNCRC, and advance policies and laws relevant to young people, criticisms have also emerged regarding the establishment of such an Office. For instance, concerns have surfaced over the issues that such 
an Office might raise; the impact on funding allocations for other services to assist children, whether the Human Rights Commission should adopt this role, and whether the Commissioner's role should be to focus on certain groups of vulnerable children such as Indigenous populations (Canadian UNICEF Committee, 2010).

As a former Canadian Senator for Children (1994-2005) and dedicated advocate for children's rights, the Honourable Landon Pearson O.C. offers her reflections and shares her experiences, insights, and perspectives in the following interview on the need for a Commissioner for children and youth in Canada. In addition to her time as a former Senator, Mrs. Pearson's experience includes her role as an Advisor on children's rights to the Minister of Foreign Affairs, her work as a personal representative of Prime Minister Jean Chretien to the 2002 United Nations Special Session on Children, in her role as Vice-Chairperson of the Canadian Commission for the International Year of the Child (1979), President and Chair of the Canadian Council of Children and Youth, as well as a founding member and Chair of the Canadian Coalition for the Rights of Children. She has been a dedicated volunteer for various organizations involving children worldwide, and is the founder of the Landon Pearson Resource Centre for the Study of Childhood and Children's Rights at Carleton University. As a life-long children's advocate, her vast experience informs her perspective on the potential role and function of a Commissioner for Canada's children. With her long involvement in decisionmaking processes, Mrs. Pearson provides important recommendations to advance the field of child and youth advocacy in Canada and abroad.

Over 20 years ago, Mrs. Pearson put forth a recommendation to establish a federal Commissioner for Canada's children (Pearson, 1997, p.12). Subsequently, in 2001, she and her parliamentary colleague Karen Kraft-Sloan produced the report titled A Commissioner for Canada's Children (Pearson \& Kraft Sloan, 2001), updated in 2016, describing the potential role for a Commissioner in Canada. Considering the current gap in literature surrounding the role of independent child and youth advocates in Canada, this report is particularly important because it outlines the potential role and function of a federal Commissioner for Canada's children. A Commissioner for Canada's Children noted the following recommendations (pp. 5-6): 
- Work with federal departments and parliamentary committees to promote a higher political priority for children and give greater visibility to children's issues within government and civil society;

- Work to improve public attitudes to children and increase public awareness of children's rights by developing advocacy programs;

- Identify policy issues relevant to children;

- Provide advice to federal departments on issues of concern to children;

- Ensure that departments and parliamentarians have access to the best possible research on the impact of proposed policies on children;

- Engage children and their natural advocates, especially parents and their family members;

- Liaise regularly with the Canadian Council of Child and Youth Advocates, Aboriginal youth serving organizations and other stakeholders; and assist federal departments to organize consultations with young people and their advocates.

A number of organizations have taken up the call for a federal Children's Commissioner including the Canadian Coalition for the Rights of Children, Canadian Pediatric Society, Canadian Student Association for Children's Rights, Child Welfare League of Canada, Children First Canada, members of the Prime Minister's Youth Council, UNICEF Canada, and the United Nations Committee on the Rights of the Child. Through various initiatives and activities, they have lobbied Canada's government to establish a Commissioner for children at the Federal level. There have been several attempts between 2009-2015 by private members in government to introduce bills (Bill C-418: An Act to establish a Children's Commissioner of Canada the Children's Commissioner Act; Bill C-420: An Act to establish the Office of the Commissioner for Children and Young Persons in Canada; Bill C-701: An Act to establish the Office of the Commissioner for Children and Young Persons in Canada, $2^{\text {nd }}$ session) yet none of these private members' bills were passed (The Canadian Bar Association, 2017).

Nevertheless, the interest in establishing a federal Children's Commissioner continues (Canadian UNICEF Committee, 2010; Senate of Canada, 2007; United Nations Committee on the Rights of the Child 2003, 2012). Given that Canada's population is comprised of over nine million children, supporters insist that a Commissioner at the Federal level of government should have a mandate that represents their interests (Canadian UNICEF Committee, 2010). According to the Canadian UNICEF Committee (2010, 2), “An independent national Children's 
Commissioner would put children's best interests on the public agenda, encourage different departments and orders of government to coordinate their efforts and promote better laws, policies and services for children." Although Canada ratified the UNCRC over 25 years ago, it is timely to consider how to turn promises into realities and help advance children's rights in this country through the establishment of a Commissioner for children.

\section{Interview with Landon Pearson}

In the interview that follows, Landon Pearson unpacks some of the debates surrounding the establishment of a federal Children's Commissioner and provides an important perspective on the role and function of a Commissioner for Canada's children and youth.

\section{Q1: Does the absence of a Commissioner for children and youth affect Canada's ability to advocate for children and youth and some of the challenges that they face? If so, how?}

We simply do not have a capacity at the federal level of government to advocate for and with children and youth and that means that children's issues fall off the political agenda as soon as something else takes priority. For example, the Trudeau government's focus on women and girls seems to have moved Canadian international development assistance away from promoting overall child protection from a rights-based perspective. Gender is important but you cannot solve gender issues without looking at the social and cultural, not to say economic and political context of early childhood, you just can't.

In my view, in the world today, there are two major sources of challenges to children's rights; armed conflict and climate change. In both cases, children are the most affected. To focus on women and gender or on early and forced marriage without taking these two challenges into consideration is to focus on consequences, not causes. Because of climate change and armed conflict in so many parts of the world, billions of children are unschooled, undernourished, starving, or at risk of violence. In the Middle East, Nigeria, South Sudan and Somalia, the situation is disastrous and vast numbers of children are going to be permanently damaged, if they survive at all, because of what is happening to them. Often climate change and armed conflict are intertwined and I have to say that most of our domestic issues in Canada pale in significance compared to what is going on in other parts of the world where, alas, progress in addressing 
these challenges is minimal in spite of the humanitarian instruments we have put in place, like the UNCRC. Child soldiers are still being recruited and little girls are being raped.

\section{Q2: Which group(s) of young people 'fall through the cracks' in the absence of a}

\section{Commissioner for Canada's children and youth?}

In Canada, while armed conflict and climate change do not affect children as directly as they do in other parts of the world they amplify the vulnerability of certain groups of children who are already falling through the cracks for other reasons such as refugee, immigrant and Indigenous children and youth. However, it is becoming clear that Indigenous children who are living in Northern and remote communities are actually being affected by climate change as well as by all the other issues related to their well-being that fall under federal jurisdiction.

Since Canada's Criminal Code is federal, children in conflict with the law also risk 'falling through the cracks' even though the implementation of the Youth Criminal Justice Act is provincial. One of the primary reasons that the rights of these children in conflict with the law are not adequately respected is that it is difficult owing to our federal structure to pull together national strategies. This also applies to child welfare which is under a provincial jurisdiction as well as child health. Yet the federal government has responsibility for health promotion and for research. The federal government has established a mental health commission to be held accountable for making children's mental health a priority which is a good start but it has not yet shown itself capable of addressing such a major problem with any real clout.

Another group of children who do not get enough attention are the large numbers of children of separation and divorce. For example, if a parent takes a child across provincial borders they encounter a different regime in terms of collecting child support payments. The Divorce Act is federal and the implementation of it becomes complicated - if somebody has not paid child support then who goes after this person? Is it the feds or the province? It all comes down to the fact that coordination needs to be improved in all over-lapping areas and having a Commissioner who would be able to focus on issues like this, would really help. 


\section{Q3: In what ways could the Canadian Council of Child and Youth Advocates work together or with a Children's Commissioner to improve child and youth advocacy in this country?}

I think it would be very helpful for the two to nurture a connection. My general impression is that the Council is not very strong at the moment; it meets only once a year and leadership can be problematic. There is potential to make the Council stronger because a Commissioner could give the provincial and territorial advocates more access to both national and international information and this knowledge transfer would really help. It would be important to investigate how a Commissioner could work with individual advocates to establish the communication and organisational structures that would be most effective for the flow of information. At the moment, the sharing of child-related issues is a messy process. There are too many uncoordinated routes. If the perception of what the provincial and territorial advocates do could be strengthened, then more organizations would work with them and allow them to channel through information and ideas to the federal level of government where many policies affecting children originate. For instance, when Canada makes its periodic report to the UN Committee on the Rights of the Child, the provincial and territorial Advocates now make a separate submission but trying to get the correct information to the Committee is challenging. It would be a natural task for the Commissioner to help improve the lines of communication.

\section{Q4: What should the role and/or function of a Commissioner for Canada's children and youth look like?}

I do not think the Commissioner should take on individual advocacy cases as part of his or her role. To so do takes so much energy and time. In my experience, when it is known that there is an opportunity to bring forward a complaint, many people leap at the chance. The Human Rights Commission, for example has found much of its budget swallowed up by individual case work. When the case is an exemplary one like the First Nations Child and Family Caring Society (in conjunction with the AFN) complaint with respect to discrimination against First Nations children in child welfare which the Commission sent on to the Human Rights Tribunal for adjudication, this is worth all the enormous effort that has been demanded. I would prefer a Commissioner for children and youth to focus on defining issues that specifically relate to children's rights and coordinate the flow of information about them pressuring government to 
do the right thing. There are some issues related to children that may not appear to implicate their rights but in fact, almost all of them do when you use the UNCRC as a framework. For example, on custody and access issues, the Commissioner could help ensure that provincial judges and other professionals involved maintain a child rights perspective.

A Commissioner would have to be a good diplomat; a person able to build connections and relations. The structure of the office of the federal Commissioner would, of course, have to give an important role to issues related to Indigenous kids. Whether that would mean a CoCommissioner or not should only be agreed upon after a great deal of consultation with Indigenous groups as well as with groups concerned with children with disabilities, with refugees and immigrants and, very importantly, with children and youth. What I would worry about is that the government would put together a structure first without consultation and then reach out.

In my view, it is imperative to build the communications first or there will be resistance to the design. This would be an excellent challenge for a qualified person who could be charged with developing a working group as was done to transform the UN Declaration on the Rights of the Child into the UNCRC. Even though that working group took ten years, what emerged was a much better and more acceptable product than would have been the case if some officials had simply drafted it. I think that is what the government should do, create a working group with a good chair, somebody who knows how to get people to say things honestly, to develop three or four models over a couple of years with considerable consultation and then come forward with a proposal to the federal government saying 'this is what it should look like.' There should be discussions with the people who run offices for the Commissioners for Official Languages, Privacy, and Freedom of Information. A Commissioner for Children and Youth is a very specific role but I can see a viable model emerging this way, avoiding serious mistakes. A good working group chair would be necessary to create the role but that person should not become the Commissioner. I would suggest as chair someone with a legal background because so much of what affects children and youth at the federal level is embodied in legislation. This person should also know something about kids possibly with social work, teaching or health professional experience. It should be someone who knows the UNCRC and understands children's rights. I also think it should be somebody from outside of government. Once the model has been designed 
then it would be known whether it is necessary to have Co-Commissioners with one to focus on Indigenous kids.

I have seen for many years how easy it is for politics to trump common sense. That's been my experience as a board member of the First Nations Child and Family Caring Society as I have observed how the government does not consult when it should. This is another reason why I believe that the Commissioner or Commissioners should have knowledge of the law and understand the Constitution. The office of the Commissioner should adopt the Child Rights Impact Assessment instrument that is already in use elsewhere to examine policy and legislation. Mind you, I think that is something the Department of Justice should be doing now when drafting any legislation relating to children. Furthermore, the obligation for the Commissioner to look at everything from a child-rights point of view would be an important way of increasing Canada's implementation of the UNCRC. An additional role of the office should be communication with kids in order to advocate for their general concerns if not for their individual complaints. In Sweden this was done. Every week they put a new question on the Internet and kids responded. Then a section of the office analyzed what children were thinking. It happened in Scotland as well and I hope it still does. There should also be a focus on identifying issues and on exploring solutions. The Office of the Commissioner must be transparent. Open communications are important because they help to make the Convention widely known to adults and children alike as required by UNCRC article 42.

Other roles of the Office of the Commissioner would be to focus on clusters of children's rights issues; address human rights education generally and provide more funding for the development and dissemination of child rights materials for the use of parents and teachers.

\section{Q5: Would a separate role be required to help address issues involving Indigenous children?}

From my experience, focusing on Indigenous issues is easier said than done. The very first thing that has to be done to ensure effective action is to build trust and building trust takes years. So patience is important, and in the meantime, for those who are less patient, I think money for scholarships and bursaries is a straight forward and good investment for Indigenous 
youth. This is an excellent way to create a new generation of competent people. 'Right to Play' supports sport activities in remote communities which is also very useful. It is the painful issues related to mental health that have to do with the long standing inter-generational transfer of trauma that are the most difficult to address, but, in the end, they must be resolved.

I personally believe that investing in the training and deployment of Indigenous midwives is important and that is something a federal Commissioner could promote to the First Nations and Inuit Health Branch of Health Canada. Birth should be returned to the community to strengthen the connections between the young mother and her significant others. By sending mothers out of the community to have their babies the possibility of the father being there is foreclosed and if it is not the first baby, the baby's siblings can feel abandoned. It is a colonial point of view that physical health is more important than emotional health. The idea is prevalent that 'we have to take them out of their community to prevent high risk births.' Perhaps it is better to take the risk that there might be some problems with the birth than risk an infant being damaged by removing his or her mother from all emotional supports. Funding mid-wifery programs and increasing the numbers of trained Indigenous health professionals to help look after children are the kinds of things that outsiders can do to improve the situation in many Indigenous communities.

What outsiders cannot do (unless they are prepared to live there for many years) is deal with issues such as sexual abuse which are at the root of so many of the problems that are going on in those communities - where there are 'offending uncles' in small communities and everybody knows who the perpetrators are. Sexual education is minimal which is problematic because the federal government, as I have just noted, is responsible for the health of First Nations and Inuit children and Health Canada has prevention in its mandate. Also, as a federal department, it has a capacity to set standards that provincial advocates do not have.

\section{Q6: In your opinion, is there a difference between an ombudsman and an advocate?}

An 'Ombudsman,' conceptually, is someone who takes a case. According to the Oxford Dictionary, an Ombudsman is "An official appointed to investigate individuals' complaints against a company or organization, especially a public authority" (Oxford University Press, 2017, para. 1). In this context, an ombudsman would be the person who would deal with particulars whereas an advocate has a broader role - that's my understanding of the difference 
between the two. Sparking the creation of most provincial or territorial Child and Youth Advocate's Offices was a tragic case related to the death of a child that raised enough attention to make a child advocate politically saleable. Responding to individual tragedy is rarely seen as a federal responsibility yet, in truth, it is the responsibility of all of us. Respect for children's rights, as for all human rights, imposes an obligation on society to create the conditions in which all individuals and especially children can flourish. While a Commissioner might not be able to address a specific situation in the way that an ombudsman could, he or she or they could do a lot to improve the general conditions in which children in Canada are born and grow up as well as those who come to us from abroad.

\section{References}

Bendo, D. (2016). The Role of Canada's Child and Youth Advocates: A Social Constructionist Approach. MA Thesis. Brock University, Child and Youth Studies Department. Retrieved from https://dr.library.brocku.ca/bitstream/item/10530/Brock_Bendo_Daniella_2016.pdf?sequ ence $=1 \&$ isAllowed $=y$ [ accessed 25 March, 2017].

Bendo, D. (2015). Children Have Rights, Right? Child Advocacy in the Lives of young People", Youth Voice Journal May, 1-26. Retrieved from: https://youthvoicejournal.com/2015/05/22/daniella-bendo-2015-children-have-rightsright-child-advocacy-in-the-lives-of-young-people/ [accessed 25 March, 2017].

Canadian UNICEF Committee. (2010). It's Time for a National Children's Commissioner for Canada. Toronto Ontario, CA: UNICEF.

Howe, R. B. \& Covell, K. (Eds.) (2007). Children's Rights in Canada - A Question of Commitment. Waterloo, ON: Wilfrid Laurier University Press.

Mitchell, R.C. (2015). "Re-theorizing child citizenship through transdisciplinarity." In Vandenhoule, W., Desmet, E., Reynaert, D. \& Lembrechts, S. (Eds.), New Handbook on Children's Rights [Studies], (164-182). New York and London: Routledge. 
Mitchell, R., \& Moore, S. (Eds.). (2012). Politics, Participation \& Power Relations: Transdisciplinary Approaches to Critical Citizenship in the Classroom and the Community. Rotterdam, Boston and Taipei: Sense Publishers.

Oxford University Press. (2017). Dictionary: ombudsman. Retrieved from https://en.oxforddictionaries.com/definition/ombudsman [accessed 08 May, 2017].

Payne, L. (2002). Policy Review - Children's Commissioners. Children \& Society, 16(3): 284286.

Pearson, L. (1997). Seen and Heard: Children's Rights in Foreign Policy. The University of Manitoba: Department of Foreign Affairs and International Trade. Retrieved from http://www.international.gc.ca/odskelton/pearson bio.aspx?lang=eng\&view=d [accessed 20 July, 2017].

Pearson, L., \& Kraft Sloan, K. (2001). A Commissioner for Canada's Children. Retrieved from http://www.landonpearson.ca/uploads/6/0/1/4/6014680/proposal_for_a_childrens_commi ssioner_2001.pdf [accessed 25 March, 2017].

Press, J. (2017, February 22). Liberals facing calls to create children's commissioner, follow through on campaign promise. The Canadian Press. Retrieved from https://www.thestar.com/news/canada/2017/02/22/liberals-facing-calls-to-createchildrens-commissioner-follow-through-on-campaign-promise.html [accessed 15, July, 2017].

Senate of Canada (2007). Children: The silenced citizens - Final report on effective implementation of Canada's international obligations with respect to the rights of children. Ottawa, ON: Standing Senate Committee on Human Rights. Retrieved from http://www.parl.gc.ca/Content/SEN/Committee/391/huma/rep/rep10apr07-e.pdf [accessed 25 March, 2017].

The Canadian Bar Association. (2017). Independent Human Rights Institutions for Children. Retrieved from http://www.cba.org/Publications-Resources/Practice-Tools/Child-RightsToolkit/theSystem/Independent [accessed 15 July, 2017]. 
The Landon Pearson Resource Centre for the Study of Childhood and Children's Rights. (2017). Biography. Ottawa, CA: Carleton University. Retrieved from https://carleton.ca/landonpearsoncentre/landon-pearsons-biography/

Thomas, N., Cook, M., Cook, C., France, H., Hillman, J., Jenkins, C., Pearson, T., Crowley, A. (2010). Evaluating the Children's Commissioner for Wales: Report of a Participatory Research Study. International Journal of Children's Rights, 18(1): 19-52.

United Nations Committee on the Rights of the Child. (2003). Concluding observations/ comments: Canada. Geneva: United Nations.

United Nations Committee on the Rights of the Child. (2012). Concluding observations/ comments: Canada. Geneva: United Nations.

United Nations. (1989). Convention on the Rights of the Child. New York: United Nations General Assembly. 